\title{
Religious Factors in the Nigerian Public Sphere: Burdens and Prospects
}

\author{
Jacob Kehinde Ayantayo*
}

\begin{abstract}
The main thrust of this paper is that religious factors in the Nigerian public sphere have not received much scholarly attention. This is the gap the paper fills as it highlights religious factors in the Nigerian public sphere, which are exemplified in the spiritualisation of politics and election, the interpretation of political manifestoes, voting patterns, the choice of candidates and party leadership, oath swearing into office; the design and execution of political policy, to mention but a few. Attention is also paid to the implications of the above variables for the promotion of political ethics and ideologies. Data obtained from interviews with randomly selected political functionaries along with political historical documents were analysed and discussed within the ambit of functional theory of religion. Having examined the burdens and prospects inherent in the discourse, the paper recommends ways of making religion a continuous veritable tool for promoting good governance in Nigeria.
\end{abstract}

\section{Résumé}

Cette étude vise essentiellement à démontrer que les facteurs religieux dans la sphère publique nigériane ont peu intéressé les intellectuels. Elle se propose donc à combler ce vide, en mettant en relief les facteurs religieux dans la sphère publique du Nigeria, à en juger par la spiritualisation de la politique et des élections, l’interprétation des manifestes des partis politiques, les modes de scrutin, le choix des candidats et des dirigeants du parti, les cérémonies d'investiture, la conception et la mise en œuvre des mesures de politique, parmi d'autres exemples. Les implications de ces variables pour la promotion de l'éthique et des idéologies politiques ont été également abordées. Les données

* Department of Religious Studies, University of Ibadan, Ibadan, Nigeria. E-mail: kehindejacob@yahoo.com. 
obtenues à partir d'interviews menées avec des personnalités politiques sélectionnées au hasard aussi bien que des documents historiques politiques ont été analysés et débattus dans le cadre de la théorie fonctionnelle de la religion. Après examen des fardeaux et perspectives inhérents aux discours, l'étude fait des recommandations sur les voies et moyens de transformer la religion en un véritable outil permanent de promotion de la bonne gouvernance au Nigeria.

\section{Statement of the Problem}

Though public sphere discourse is multidimensional and multidisciplinary in content and context (Jürgen 1990:30), the religious factors in it has not be given sufficient attention because of the belief in some quarters that religion is a private matter which has no relevance in public domain (Ajayi and Ikara 1985). In the context of this work, the term 'public sphere' in the words of Hauser Gerard refers to an area in social life where people can get together and freely discuss and identify societal problems, and through that discussion influence political action. That is to say 'public sphere' is 'a discursive space in which individuals and groups congregate to discuss matters of mutual interest and, where possible, to reach a common judgment' (Gerard 1998:86). In the context of this definition, Fraser Nancy describes the public sphere as 'a theatre in modern societies in which political participation is enacted through the medium of talk' and 'a realm of social life in which, public opinion can be formed' (Nancy 1992:109-142). What can further be generated from the above is that 'public sphere' presupposes participatory democracy which by implications rests on the capacity of, and opportunity for citizens to engage in enlightened debate. This brings to the limelight the relevance of public opinions which essentially are characterised by attitudes, perspectives and preferences of a population towards events, circumstances and issues of mutual interest. It ultimately snowballs into political action, thus making public opinions a tool in the public sphere, for steering political activities relating to formulation and execution of governmental policies, ranging from social to economy, science to technology and education to business, among others. At every point, government is expected to listen to the public sphere; this makes for legitimate government. It is important to note that at the point of taking political decision, religion has a way of influencing the public sphere. For example, in Nigeria, religion is always a factor in the public sphere as exemplified in 'sacredising', 'sacrilegising' and 'colourising' of politics and election, interpretation of political manifestoes, voting patterns, choice of candidates and party leadership, swearing of oath of office, designing and execution of political policy. 
This subject matter is approached from historical and analytical points of view. This becomes expedient, given the fact that governance and public sphere by nature are inherently historical; hence the need to dig deep into the history of religious occupation of the Nigerian public sphere. We cover the periods such as pre-colonial, colonial, post-colonial and contemporary times in Nigeria during which, religion qua religion could be said to have influenced, both negatively and positively, the Nigerian public sphere. In the light of this, relevant political, official cum historical and non-historical documents such as dailies, periodicals, the constitution, national anthems and national pledge among others were collated and scrutinised with a sociological tool which has its roots in the Durkheim functional theory of religion. The theory asserts that religion is a functional element in society (Durkheim 1961:52). The information gathered from such an enterprise would be harnessed with information gathered through interviews from selected political functionaries, actors and actresses in Nigeria. The work, however, in addition would look objectively and analytically at the burdens and prospects inherent in the religionisation of the public space in Nigeria.

In terms of scope, the work is divided into five sections covering religious factors in the Nigerian public sphere, manifestation of religious factors in the Nigerian public sphere, burdens and prospects, concluding remarks and finally, recommendation, which is geared at making religion qua religion a continuous veritable tool for promoting good governance in the Nigerian public sphere on the one hand and African public sphere on the other hand, now and in the future.

\section{Religious Factors in the Nigerian Public Sphere}

What we intend to demonstrate in this section is that religion qua religion occupies significant space in the public sphere, using Nigeria as a case study. This is manifested in the reading of religious meanings into the conception, understanding and workability of the African public sphere. This tends to suggest that religion and politics intertwine as far as Nigeria is concerned. This development, no doubt is a clear manifestation of the popular Mbiti thesis that Africans are notoriously religious, and each person has its own religious system with a set of beliefs and practices. Religion permeates all departments of life so fully that it is not easy or possible always to isolate it (Mbiti 1969:1). Relating this to politics brings to mind the idea of theocracy, which is a government by a god/God that is, a kind of polity in which, God is regarded as the sole sovereign and the laws of the realm are regarded as divine commands. In practice, theocracy manifests in the belief that God is the political king, ruler or leader who rules his people indirectly through a set of people (leaders). These rulers in the words of Mbiti (1980:82) are regarded 
as earthly viceroys or earthly vicegerent in traditional African societies. It is interesting to note that belief in theocracy is also cardinal in Islam (Qur'an III; verse 27) and Christianity (Roman 13:1-3). Under such an arrangement, the state is seen as the enforcement and necessary agency of religion because of the tendency of people to deviate from societal norms but to depend on religion for its authority. This perhaps further explains why many African nations and even advanced nations in history were subordinated to the religious institution in their acts of governance. For example, we remember in history, the theory and practice of church-state relations the world over, especially in the medieval Europe prior to the 18th century enlightenment age when educated people thought that beliefs should depend on reason and scientific proof (Johnstone 2001:131). While advanced nations like the US severed religion from their polity, the Nigerian nation still invokes religious sentiments in acts of governance. However, there has been much demand today for the separation of religion from politics, so that each could exist on its own without undue interference. The workability of the total separation remains in doubt as religion continuously manifests in her body polity, including its public sphere.

\section{Manifestation of Religious Factors in the Nigerian Public Sphere}

It is worthy of note at this point that religious practitioners and, in fact, religious institutions are integral part of the Nigerian public sphere. They have capacity to influence politics and society. At group or sub-group levels, religious practitioners do meet, freely discuss and identify societal problems, and through such discussion influence political action. This is done by interpreting religiously governance in its entirety, especially as it relates essentially to policy formulation and the execution of public import. In other words, every governmental apparatus, political power, authority and control are coated with religious flavour and they therefore provide a basis for government legitimacy and the need for obedience to constituted authority. The government officials too, do influence the public under religious canopy in marketing and implementing their political policies. This feeling is expressed in the conception of political power and nation, political manifestoes, voting patterns, choice of candidates and party leadership, and swearing of oath of office. We shall prove this assertion below.

\section{Conception of Political Power and Nation}

An average Nigerian public believes that political power is of God and whoever gets the power must have got it from God. This perhaps is the basis of the popular dictum that 'the voice of man is the voice of God'. Nigerian Christians are fond of quoting the Bible stating that all authority is ordained 
by God while Muslims also explain the concept of political power and nation as something that have their bases in Islamic principle of unity, which form part of Islamic predestination theology (Khan 1993:23). Even ordinary election results, which are man-made and mere practical political action, are explained in religious terms. It is amazing that the so-called losers in the April 2007 general elections who wanted to challenge the mass rigging in the elections in courts and tribunals were advised against such decision, to leave everything in the hand of God. In our estimation, this practice is anti-public sphere in theory and practice at a time when there is a need to correct social ills in our contemporary governance.

The concept of a nation which, to political scientists, is just a human community possessing an historic territory, shared myths, symbols, and memories, a common and distinctive public culture, and common laws and customs for the members, is interpreted by an average Nigerian as a religious based community. This mentality is impeccably reflected in the preamble of the Nigerian Constitution which states as follows:

We the people of the Federal Republic of Nigeria, having firmly and solemnly resolved, to live in unity and harmony as one indivisible and indissoluble sovereign nation under God, dedicated to the promotion of inter-African solidarity, world peace, international co-operation and understanding and to provide a Constitution for the purpose of promoting the good government and welfare of all persons in our country, on the principles of freedom, equality and justice, and for the purpose of consolidating the unity of our people, do hereby make, enact and give to ourselves the following Constitution (Nigerian Constitution 1999). (the italic is mine )

Adjunct to that is the ending of Oaths of Allegiance sworn by public officers with the word ...So help me God. However, this practice which is not peculiar to Nigeria falls under what Jonathan Smith labels as civil religion, which refers to the set of religious or quasi-religious beliefs, myths, symbols and ceremonies that unite a political community and that mobilise its members in the pursuit of common goals (Smith 1995:275). According to Jean-Jacques who was the first to use the term, civil religion implies that:

there is a purely civil profession of faith, the articles of which it behoves the sovereignty to fix, not with the precision of religious dogma, but treating them as a body of social sentiments without which, no man can either be a good citizen or a faithful subject (Barker 1960:305-306).

The idea of civil religion refers to the view of some people that the foundation of their societies and the events that mark its progress through history are parts of a larger, divine scheme of things. This thesis could also best explain religious coloration of Nigerian national symbols such as currency, 
statue, tower, national anthem and national pledge. These symbols among others are of national significance because they signify common national traits which, by implication, remind Nigerians of their origin, history, and political development. Such consequently propels them to work in unity as people of common identity and origin.

\section{Choice of Candidates}

Election time always provides an opportunity for the public to get together, freely discuss and identify societal problems inherent in politics, and through that discussion influence political action by nominating or selecting candidates of their choice. One of the problems is whipping of religious sentiment into public matters in such a way that interests of people belonging to different religions are safeguarded. At this time, supporters of almost every candidate for public office at all levels can be heard during the campaign talking about trying to get the 'Catholic vote', 'Muslim vote', 'Baptist vote' or 'Pentecostal vote'. Such interest, according to Johnstones, gives very explicit recognition to the correlation that exists between religious affiliation and commitment on the one hand and voting behaviour on the other hand (Johnstone 2001:134). In Nigeria, such practice is spearheaded by religious bodies such as CAN (Christian Association of Nigeria) and the Supreme Council of Islamic Affairs (SCIA) in such a manner that the choice of a candidate to a public office is made with reference to his/her religious affiliation. At this point, we hear of Christian/Muslim or Muslim/Christian ticket. This is common where we have two positions running concurrently such as those of President and Vice President, Governor and Deputy Governor. This practice is evident in the leadership of the nation as shown below:

1. Nnamdi Azikiwe/Tafawa Balewa (Christian/Muslim) 1960 - 1966

2. Shehu Shagari/Alex Ekwueme (Muslim/Christian) 1979 - 1983

3. Buhari/Idiagbon (Muslim/Muslim) 1983-1985

4. Babangida/Ebitu Ukiwe, Aikhomu (Muslim/Christian) 1985-1993

5. Shonekan/Abacha (Christian /Muslim) 1993 - 1997

6. Abacha /Diya, (Muslim/Christian) $1997-1998$

7. Abubakar/Akhigbe (Muslim/Christian) $1998-1999$

8. Obasanjo/Atiku (Christian / Muslim) 1999 - 2007

9. Yar’Adua/Jonathan (Muslim/Christian) 2007 to date

\section{Religious Law as Bait During Electioneering Campaign}

In history, a few politicians used possible entrenchment of the laws of a particular religion as a bait to secure the votes of practitioners of such religion. For example, the immediate past Governor of Zamfara state, Alhaji Yerima, during his electioneering campaign in 2003, promised the northern 
Muslims that Sharia laws would be introduced in the state if Muslims voted for him. On the basis of this, he got elected and on getting to power,he made the state an Islamic state with the introduction of Sharia law. However, the development had since then generated controversy among Christians and Muslims in the state because Christians in the state complained of being denied their religious rights and freedom (Ayantayo 2005:55-64).

In the same year, 2003, Major General Buhari of the ANPP adopted the same strategy when he was alleged to have advised Muslims not to vote for Christian candidates but Muslim candidates. This development has also generated argument, counter-argument and war of words in the media and public forum among Christians and Muslims. Christians did not only condemn the standpoint of Buhari but they also demanded a public apology from him (Nigerian Tribune 2003:13). Save for several appeals from the CAN and individual Christians, the controversy could have degenerated into a religious war. On the account of this, we can argue that whipping of religious sentiments is a serious issue posing threats to democracy because of the danger inherent in it. Perhaps, it is in the light of this that Ahanotu exclaims that:

The struggle on how the Muslim or Christian communities will live and be governed in the modern state Nigeria has produced mutual fear, suspicions and tension. There is religious shivering, certain verbosity and quite a bit of irritation in both communities (Ahanotu 1992:89).

\section{Use of God Language}

Religion is brought into the election process through the use of God and religious language rather than political language which pervades political manifestoes, which parties or individual contestants intend to offer the public in order to convince them about the need for them to be voted for. This practice was pronounced during the second republic (1979 and 1983). For example during the electioneering campaigns of the National Party of Nigeria in 1979 and 1983, the party made bold of the fact that it meant well for the nation because it was the only party laid on religious foundation. On the account of this, it appealed for one Nation with one Destiny under one God. Some northern Christians interpreted this to mean that Islam is being placed over and above Christianity in Nigerian politics. This generated acrimony and insinuations in some quarters on the ground of the assumption that the National Party of Nigeria (NPN) was designed to advance the course of Islam against Christianity. It is no wonder why some Christians in that circle likened the idea of raising one finger as the logo of the party during electioneering campaign to mean one religion, which is Islam. Given this, Muslim politicians in the northern Nigeria conclusively interpreted the raising of two 
fingers by the Unity Party of Nigeria, to mean two Gods/gods which, is tantamount to polytheism. For this singular reason, Muslims in the northern part of the country were enjoined not to vote for the Unity Party of Nigeria. According to Hassan Kukah, the concept of one Nation with One Destiny under God, which was advanced by the N.P.N., was an extension of the old Nigerian People Congress's (NPC) One North, One People. He adds that the same was also set within the context of the politics of the late Sardauna of the northern ruling class (Kukah 1993:146). One could be tempted to subscribe to Kukah's thesis because in the northern part of the country, especially during the first republic, religion was a factor in advancing the political interest of the northern elites. Alliances among parties were formed with religious considerations. For example, when NEPU went in alliance with NCNC, a southern party, they were projected as people who had sold out their religion. In the same vein, those who were not in the fold of the NPC were regarded as traitors who had deviated from the path of God, the idea that the party had constantly advanced. It is important to note at this juncture that it had been the Article of faith within the northern Caliphate that 'the hand of God is on the community and he who sets himself apart from it will be part in the hell. He who departs from the community by a hand span ceases to be a Muslim (Dudley 1968:143).

Based on the fact that religious sentiment had some attraction for the process of political bargaining, in 1983, the presidential candidate of National Advance Party, Dr Tunji Braithwaite, changed his political agenda from a plan to eradicate rats, mosquitoes, cockroaches, etc., to take the nation back to God as an answer to national paralysis, spiritual decay and callousness (Miles 1988:72). It is interesting to note that at the end of various elections that year, the NAP did not win a single seat at any level. This is suggestive that God apparently may not have anything to do with the election or that whipping of religious sentiments does not absolutely imply that someone would win an election. To our mind, the act of sensitising people to vote for a party in the name of religion is just a diversionary tactic that may or may not work well at all times. This reminds us of President Babangida's tactics of using God language precisely 'Insha Allah' (meaning by the will of Allah) whenever he was to answer questions on whether or not he would vacate office after the general elections of 1993. He was fond to saying 'Insha Allah' to prove his sincerity about his plan to vacate office for whosoever won the 1993 presidential election. Unfortunately, he annulled the election which was regarded as the freest and fairest election, even when it was said to have been won by a fellow Muslim. At the end, he was pressurised to leave the office (Olasupo 2003:145-159). 


\section{Spiritualisation of Electoral Process and Body Polity}

Spiritualisation of electoral process connotes the act of taking into spiritual or supernatural realm, thereby creating an impression that success in election is independent of wisdom, foresightedness, logical plan, widespread political tour and good campaign, adequate political logistics, and people oriented political manifestoes but by divine intervention or divine help, manipulation and inducement. For example, the CAN - Christian Association of Nigeria - Shomolu 1 Bariga Chapter recently held a prayer session for hitchfree council polls election slated for 11 October 2008 (Nation Newspaper 2008). In the same vein, after the re-run of Gubernatorial election in Cross Rivers State of Nigeria on 30 August 2008, the winner Liyel Imoke, remarked publicly that prayers reinstated him and not political diplomacy ( $\mathrm{Na}$ tion Newspaper, 2 September 2008). The impression the public and even politicians do have is that electoral issues are better settled spiritually thorough prayers, manipulation of angelic beings and the use of magic than making appeals to political wizardry. Some candidates practically demonstrated this by boasting that if certain groups of people or individuals refused to vote for them, then, some natural objects like stones, pebbles and leaves would vote for them in their stead. Counting on this, some politicians did express their much reliance on the power of prayer or magic to win elections. This also goes with the use of charm, magic and occultic powers to either threaten political opponents to withdraw in election contest or at times to threaten electorates not to vote for candidates of their choice, even after they might have been convinced of the need to do so, going by the content of political manifestoes such party or individuals might have presented to the populace during campaigns. Some equally used magic to hypnotise voters to vote for them or for a particular party against the party they initially had in mind. Though we do not have statistical data at hand to practically demonstrate the degree at which the religious methods mentioned above had worked or are working, we cannot deny the fact that they are issues during election periods in Nigeria, and that they negate the spirit of democracy.

Our contention at this juncture is that, laying emphasis on religion as against other factors, like political manifestoes, as those influencing voting decision is dangerous to democracy. This point is arguable in that democracy always makes provision for freedom of choice as regards which party one should vote for with attention paid to political manifestoes presented to the electorate during the campaign exercise. Therefore, to blindfold voters with religious sentiment would amount to diverting them from the appropriate direction - political manifestos that have capacity to influence which candidate or party should be voted for. The practice of holding constant and organised prayer sessions to influence governmental policies in public offices and outside 
it in places like schools, churches, universities, mosques, shrines, market places and stalls is another way by which religion is used to influence the Nigerian public sphere. This exercise is captioned as 'Nigerians pray' and is been coordinated by General Gowon, former Nigerian Head of State. The prayer sessions were characterised by many prayer points geared towards making Nigerian government humane.

\section{Religion as Mobilisation Tool of Implementing Government Policy}

This is manifested in the use of religion by policy makers to convince the populace about the need to appreciate and allow government policy to function. At this point, religious belief is explored as a tool to implement government policy. For example, the government of Lagos State in Nigeria of recent used selected Christian and Islamic religious leaders in paid advertisement to sensitise her citizens to pay tax as one of the sources of internally generated revenue (IGR). This view is expressed in the advert within the contexts of the following pictorial settings: We have the inscription stating 'You are obeying God's word when you PAY YOUR TAX; there is a bold picture of Pastor Adeboye, the General overseer of the Redeemed Christian Church; a small picture was inserted near the picture of the religious leader to suggest that some infrastructures are waiting for government funding; following this is a lengthy quotation reading thus: 'Let somebody shout Hallelluyah' (It is important to note that Pastor Adeboye is reputed to be fond of saying 'Let somebody shout Hallelluyah' to the extent that many people have taken the expression as his password). Our Lord and saviour Jesus Christ in Mark 12:13-17 enjoins us to give unto Ceaser what belongs to Ceaser, and this includes paying our taxes. Paying our taxes is not only a civic responsibility, but also being obedient to the word of the Lord. Now there's abundant evidence to show that the Lagos State government has made it a duty to provide improved health care facilities, better sewage disposal, better road network and transportation. To do all these, the government needs your support and cooperation. That's why I'm appealing to you, please pay your taxes Let somebody shout Hallelluyah' and finally, we have the logo of Lagos Internal Revenue Service saying: Pay your tax (Nation Newspaper 9 July 2008:A6).

Another one was published for the attention of Lagos Muslims and it appears in this manner: every religion supports payment of Tax, PAY YOUR TAX; we have a bold picture of Imam Garuba Akinola, Chief Imam of Lagos state; a small picture inserted near the picture depicting infrastructures waiting for government funding; we have lengthy quotation reading thus: 'Asalam alaikun waramotulai wabarakatum! My dear brothers and sisters in Islam, the Holy Qur'an enjoins us to discharge our civic responsibilities by paying 
our tax so that we can contribute to the progress and development of Lagos State. Tax is the vehicle through which government derives resources for the provision of social infrastructural amenities for its citizens. Let us obey the teachings of Islam by cooperating with government in the payment of our tax. Eko ko ni baje and in conclusion, we have the logo of Lagos Internal Revenue Service saying Pay your tax (Nation Newspaper, 30 July 2008:A4). In the two instances, the Lagos State Government has taken advantage of the respect that Christians and Muslims have for the two religious personalities in question to market their political policy aimed at generating resources for the running of government. The degree at which this mechanism has worked or not would be a subject of verification for sociologists of religion.

\section{Burdens Inherent in the Space Religion Occupies in the Nigerian Public Sphere}

Exploration of religion as instrument of influencing politics in the Nigerian public sphere is not without its burdens because, more often than not, the practice is tantamount to manipulation of religion, which has its attendant problems, such as intra and inter-religious conflicts. Manipulation of religion theory was popularised by Usman Bala who defines it as 'an act of controlling the action of a person or group of persons without that person or group knowing the goals, purpose and method of that control and without even being aware that a form of control is being exercised on them at all' (Bala 1987). This theory has been exemplified in various ways in which Nigerian political leaders have whipped religious sentiments in the process of interpreting some political policies and government actions, some of which have been mentioned in the preceding sections. What is alarming in the matter is that those being manipulated via religious sentiment are ignorant of their being manipulated and, ironically, they consciously or unconsciously become puppets in the hands of their users-political elites. This perhaps explains why democracy has not worked to the satisfaction of Nigerians, especially those people who believe that many of Nigerian politicians are not mature politically. The practice also has some moral implications because, in our judgement, whipping of religious sentiments to win the sympathy of electorates is a game of deceit because there is relationship between politics and morality. The relationship is very simple, given the fact that politics is a subject of moral evaluation. It is in this sense that we talk about political morality which refers to moral rules regulating political behaviour and activities such as voting, campaigning electioneering processes among others. It is also within this background, that we can associate moral values such as the following: truthfulness, accountability, responsibility, justice, faithfulness, love, tolerance and discipline with political activities. On this ground, we 
expect politicians to be truthful in governance and be disciplined in the use of power or mandate given to them by the public via election or selection processes, as the case may be. For this reason, we can argue that the use of religion as a bait to secure votes is tantamount to falsehood, which is also antithetical to democracy and good governance. The falsehood involved is detestable because it is a clear departure from the ethos of religion being used as bait, as Christian and Islamic religious traditions and scriptures are replete with moral values associated with politics generally and how politicians should behave towards good governance (Dzurgba 2003:38).

Consequently, the practice of whipping up of religious sentiments in the Nigerian public sphere has uncountable effects on the electorate, politicians and the democratic system of government itself. Such effects manifest in diverse ways and at different levels, particularly as they pertain to interreligious and inter-party relations. The use of religious law as a bait to woo a religious group to vote for a particular candidate as against the other has potentials to generate inter-religious conflicts in Nigeria. For example, the allegation that Major Mohammad Buhari once asked Muslims to vote for only Muslim candidates in the 2003 election generated cold blood between Christians and Muslims. Many rejoinders were written by Christians to protest the alleged (Buhari's) statement, which also resulted in press war on the ground that Nigeria is a civilised country and cannot afford to be drawn into religious politics and that what Nigerians want is a Nigerian who can suffer and die for the people, with good governance (Nigerian Tribune 26 February 2003).

Such political gimmick almost resulted in political and religious crisis. But for the political maturity that some Christians and Muslims exhibited, the press war could have led to another religious violence in Nigeria. The act itself demonstrates lack of patriotism and sense of selfishness on the part of politicians who use religion as a disguise to lure voters into voting for them. The act itself is unconstitutional because Section 42 (1) of the Nigerian Constitution in part states that no citizen of Nigeria shall be subjected to any disability or deprivation merely by reason of the circumstances of his birth, community, ethnic group, places of origin, sex, religious or political opinions (Federal Republic of Nigerian Constitution). The bad aspect of this development it is that political intolerance is antithetical to democracy, which presupposes tolerance of opposition. Worse still, religious colouration of election, which we likened to diversionary tactic, has tendency to lead voters to vote for wrong, incompetent candidates who could not deliver public good. This development has led to political instability, underdevelopment in politics and economy, absence or lack of continuity of government policy 
and finally bad governance in Nigeria. It is in the light of this argument that Lawal's observation is apposite when he writes that:

Nigeria's chequered political history is bedevilled with the gory tales of political instability, bad governance and maladministration...the problems of bad governance emanating from electoral crisis have had far reaching destructive impacts on Nigerian political system which, are manifested in suffering, insecurity and backwardness (Lawal 2003:125-132, p. 130).

\section{Prospects of Religious Occupation of the Nigerian Public Sphere}

Hopefully, religion, if well harnessed, has much potential to influence public sphere because by its nature, it is a group phenomenon exemplified in congregations, ceremonial gatherings, denominational prayer meetings, family pilgrimages and ecumenical councils. In history, the three major religions viz.: traditional religion, Islam and Christianity have no doubt influenced and have indeed continued to influence the Nigerian public sphere in one way or the other because of the interplay between religion and governance in $\mathrm{Ni}$ geria. In other words, religion remains an issue in Nigerian political terrain, or better, put Nigerian public domain (Smith 1971:140-169). It is so because as stated earlier and as exemplified in the words of Mbiti, Africans are notoriously religious and this accounts for their constant interpretation of the content and intent of politics through religions. This is further exemplified in the fact that Africans were/are still used to viewing government as ordained by God/god and political leaders as gods or direct agents of God. From the past to date, Nigerian societies, like many African societies, have not become as secularised as most societies of the West though this process would still surface in the nearest future. But meanwhile, the place and space that religion occupies in public cum political domain remains indispensable

From the foregoing, appropriating religion in political terrain is like a tradition which has become a way of life in Nigerian public sphere. The tradition, no doubt, strengthens and weakens political structures. It plays conflicting roles in politics. What needs to be done is to recommend ways of exploring the positive side of it and discourage the negative aspect of it. Invariably, it is not out of point to suggest that Nigerian religious practitioners should be taught and oriented on how to make good use of religion in public sphere to avoid rancour and acrimony often associated with the Nigerian politico-religious terrain. The first step is promotion of democracy education at secular and religious levels. By this we mean enlightening the public about the tenet of democracy and good governance, which includes sovereignty of the people, government based upon consent of the governed, majority rule, minority rights, guarantee of basic human rights, free and fair elections, equality before 
the law, due process of law, constitutional limits on government, social, economic and political pluralism and values of tolerance, pragmatism, cooperation and compromise (United States Information Agency, October 1991). The object of democratic education is to produce citizens who are independent, critical and analytical in their outlook, yet deeply familiar with the precepts and practices of democracy.

This type of education is expected to make it difficult for the electorate to be easily susceptible to political gimmick garbed in religious sentiment. Religion has much prospect to influence public sphere because by nature it is a group phenomenon. This is exemplified in congregations, ceremonial gatherings, denominational prayer meetings, family pilgrimages, and ecumenical councils. There are a lot of lessons to learn from the Nigerian traditional political societies where high premium was placed on the moral values, which have their roots in traditional religious beliefs and practices. Such values include responsibility, accountability, discipline, dutifulness, justice and servanthood among others. The political structure itself allows for free participation in decision making that affects the village, town, or state. In the words of Kwame Gyekye who has written extensively on chiefship and political values in Africa, the method of arriving at decisions, reflecting respect for the individual is that of consultation and consensus, freedom of expression, and openness of deliberations at public meetings and assemblies (Gyekye 2002:121). These practices, to a large extent, are important elements of the democratic principles with basis in African social morality.

Also, in Islam and Christianity, a lot could still be derived from their scriptural teachings on value-underlying politic which, in our judgement could be called political values. From the Christian religious point of view, good governance which, as a duty, must be demonstrated in good leadership in public domain as an example presupposes discharge of certain responsibilities exemplified in knowing the key to maintaining high motivation and morale within the group as Moses and Samuel exemplified good leadership in the Bible. This implies also that every Christian leader must be responsible, growing, exemplary, inspiring, efficient, caring, communicating, goodoriented, decisive, competent, unifying and hard working. For Islam, the premise for political morality is that morality is taken as an integral part of Islam. Therefore, every Muslim, irrespective of status or position, is enjoined to do the right and forbid wrong (Surah 3:104,110), be firm (Surah 8:24), be of good manner - (Surah 25:62-68), be sincere lovers of truth and witness (Surah 58:19), to discipline self - (Surah 3:152; 55:4), be just (Surah 4:40), promote justice - (Surah 21:47), be humble - (Surah 6:42-43; 7:161; 57:16); not to deceive themselves - (Surah 2:9); not to make mischief, fool or 
mockery - (Surah 2:11-12; 2:13-15). In other words, Muslims are to fulfil obligations and oaths and promises epitomised in political manifestoes, election promises and oath of allegiance sworn to before getting to office (Surah 2:224-227; 5:1; 92); to work towards political peace devoid of thuggery and political assassination which presently characterise the Nigerian political terrain. Righteousness in the Nigerian public sphere, with its basis in Surah 2:177, 207-208, 212; 3:16-17, 92,133-135,191-195; 4:36, 135; 23:70-71, 90 and 8:61, is advocated.

The impression we are trying to create here is that the shrine, the church and the mosque have a duty of educating their members about the right action to embark upon and the bad action to desist from in the public sphere and, in fact, in the overall political activities on the other hand. Corroborating the need for the mosque to offer political education from the Islamic perspective, Justice Ahmed Lemu writes that: ... there is need for proper education with the ultimate aim of facilitating the balanced growth of the total personality of man through the training of man's spirit, intellect, rational self, feelings and bodily sense (Lemu 1986:175). For the Christian, Adeogun, like Lemu, likens the church to a school for ethical development where its members, particularly political leaders (quoting Philippians 4:8), should do whatever things are true, honest, just, pure, lovely and of good report, not only in their religious centres but in public domain where they, as part and parcel of society, engage themselves in the Nigerian public sphere (Adeogun 1986:82).

\section{Concluding Remarks}

With religious approach to good governance as discussed above, it is our hope that the public generally would begin to do thorough assessments of political manifestoes as a guide towards public oriented voting decision, showing concern for merit as against bias and sentiment, and placing emphasis on past records of achievement of politicians as against whipping of religious sentiment. With this arrangement, it is likely that Nigerian politicians and the public would handle with ethical consideration the Nigerian public sphere. Careful and ethical handling of religious dimension to public sphere is an important indicator of the overall democracy which Nigerians have long yearned for. Such would consequently advance the course of democracy and development exemplified in good governance. To our mind, good governance is anchored on morality, which is fundamental to religion. It is important to note that religion is unique in claiming a higher source of societal morality because it ultimately invokes the sacred or the supernatural in order to influence the behaviour of individuals who are part and parcel of the public sphere (Manus 2006:1-26). What is necessary at this juncture is that 
Nigerians should appeal to religion positively as a condition to take the lead in advancing good governance in Africa where it claims to act as big brother. Such a choice is very much needed for Nigeria to advance as an enviable public sphere that would compete favourably with global public sphere as noted earlier somewhere (Ayantayo 2004:54-64).

\section{Bibliography}

Adeogun, E.O., 1986, 'Church as a School for Ethical Development', in Religion and Ethics in Nigeria (ed.) S. O. Abogunrin, Ibadan Daystar Press.

Ajayi, J.F. Ade and Ikara, B., 1985, Evolution of Political Culture in Nigeria, Ibadan: University Press Limited and Kaduna State Council for Arts and Cultures.

Ahanotu, A.M. (eds.), 1992, Religion, State and Society in Contemporary Africa: Nigeria, Sudan, South Africa, Zaïre and Mozambique, New York: Peter Lang.

Ayantayo, J.K., 2004, 'Globalization: A New Ethnocentric Culture with Implications on African Social Values' in International Review of Politics and Development: A Journal of the Department of Political Science and Sociology, Babcock University, Vol. 2, Number 2.

Ayantayo, J.K., 2005, 'A Sociological Examination of Interreligious Conflicts in Africa' in I. O. Albert (ed.) Perspectives on Peace and Conflicts in Africa. Essays in Honours of Gen (Dr) Abudusalami Abubakar, Ibadan: Peace and Conflicts Studies, University of Ibadan in Collaboration with John Archer Publishers.

Bala, Y.U., 1987, The Manipulation of Religion in Nigeria 1977-1987, Kaduna: Vanguard Printers and Publishers Ltd.

Barker, E., 1960, 'Of Civil Religion’ in Social Contract (ed.), London: Oxford University Press.

Dudley, B., 1968, Parties and Politics in Northern Nigeria, London: Frank Cass.

Durkheim, E., 1962, The Elementary Forms of Religious Life, Trans Joseph Ward Swain, New York: Collier.

Dzurgba, A., 2003, Nigerian Politics and Moral Behaviour: A Study in Politics and Ethics, Ibadan: John Archers Publishers Limited.

Gerard H., 1998, 'Vernacular Dialogue and the Rhetoricality of Public Opinion'. Communication Monographs 65 (2).

Gyekye, K., 2002, African Cultural Values: An Introduction, Accra: Sankofa Company.

Jürgen, H., 1990, The Structural Transformation of the Public Sphere: An Inquiry into a Category of Bourgeois Society, Cambridge Massachusetts: The MIT Press.

Johnstone, R.L., 2001, Religion in Society: A Sociological Approach, New Jersey: Prentice Hall. 
Khan, M.W., 1993, Islam: Creator of the Modern Age, New Delhi: The Islamic Centre.

Kukah, H., 1993, Religion, Politics and Power in Northern Nigeria, Lagos: Spectrum Books Limited.

Lawal, G., 2003, 'Governance and Electoral Process in Nigeria’ in International Review of Politics and Development, A Journal of the Department of Political Science and Sociology, Babcock University, Ilishan, Vol. 1, Number 2, June.

Lemu, A., 1986, ‘The Qur’anic Basis of Ethical Revolution’ in Religion and Ethics in Nigeria (ed.) S. O. Abogunrin, Ibadan Daystar Press.

Manus, C.U., 2006, 'Religion and Politics in Multi-Ethnic Society’ in Orita: Ibadan Journal of Religious Studies, Vol. XXXVII, June and Dec.

Mbiti, J.S., 1969, African Religion and Philosophy London: Heinemann Educational Books Ltd.

Miles, W., 1988, Election in Nigeria: A Grassroots Perspective, London: Lynne Rainer Publications.

Nancy, F., 1992, 'Rethinking the Public Sphere: A Contribution to the Critique of Actually Existing Democracy', Habermas and the Public Sphere, Cambridge Mass.: MIT Press.

Nigerian Tribune, 2003, ‘Cleric wants Buhari’s apology before April polls’, Reported by Sylvanus Eze, Nation Newspaper, 2008.

Olasupo, A., 2003, Electoral Violence in Nigeria: Issues and Perspectives, Lagos: Frankad Publishers.

Smith, E.D., 1971, Religion, Politics and social Change in the Third world, New York: Free Press.

Smith, J. (ed.), 1995, The Harper Collins Dictionary of Religion, San Francisco: Harper Collins.

The Constitution of the Federal republic of Nigeria (1999).

The Holy Bible.

The Holy Qur'an.

United States Information Agency (1991). 
